\title{
The Local Wisdom Behind the Intelligence of Javanese Sexual Text in Traditional Javanese Literature (An Ethnolinguistic Review)
}

\author{
Prasetyo Adi Wisnu Wibowo \\ Universitas Sebelas Maret \\ Jl. Ir. Sutami Surakarta, Indonesia \\ prasetyoadiwisnuwibowo@yahoo.co.id
}

\author{
Sundari \\ Universitas Sebelas Maret \\ Jl. Ir. Sutami Surakarta, Indonesia \\ sundari@yahoo.com
}

\author{
Aloysius Indratmo \\ Universitas Sebelas Maret \\ Jl. Ir. Sutami Surakarta, Indonesia \\ aloysiusindratmo@yahoo.com
}

\begin{abstract}
The traditional Javanese literature consists of sexual education. This research will reveal the intellectual of Javanese community with sex education that is contained in the data source of Tembang 'traditional song' as Javanese literary such as Serat Wewadining Palakrama, Serat Asmaragama, Serat Pangawikan Lakirabi, Marta Pangrawit, Serat Wirasating Wanita, and Serat Centhini. The aims of this paper is to examine the local wisdom behind the Javanese language in Javanese text that is contained of th $e$ intelligence of ethnolinguistic Javanese sexual education. The result of this research are showed that the composition of Javanese sexual texts contained a mind-set, a worldview, a life view and a local knowledge system of Javanese in sex education. Sexual intercourse is placed in a great and sacred position to lead a religiosity.
\end{abstract}

Keyword: the local wisdom, sexual text, Ethnolinguistic, Javanese literature.

\section{INTRODUCTION}

The aims of this research is to examine the local wisdom in Javanese text behind the Javanese language that is contained the intelligence of ethnolinguistics Javanese sexual education. Beside, it has special purpose to answer the problems about category and axpression in local knowledge system behind the Javanese languge in Javanese sexual education contained in six Javanese literary works that is called Tembang 'the Javanese song'. The results of this research are expected to find a mind-set, a worldview, and a local knowledge system by Javanese people in the relation of sex education.

Tembang is one of Javanese literary that containing of sexual education. This research will reveal the intelectuals of Javanese society related to sex education that is contained in six Javanese literary of tembang namely
Serat Wewadining Palakrama, Serat Asmaragama, Serat Pangawikan Lakirabi, Martha Pangrawit, Serat Wirasating, and Serat Centhini.

The reason for this research about the intelligence of Javanese sexual educations to participate in preserving the culture and inheriting it from generation to another generation. The cultural inheriting always have a balance by arranging and systematically, chronologically and appropriately reforming the cultural elements according to the real position. Sexual educations in Javanese society is one of nobler cultural elements and containing high cultural values. The original heritage of our ancestors needs to keep and preserved so the next generation does not lose the track. There are noble says (in javanese called pitutur), typically terms to call male or female genitals, there is a special term for intercouse techniques and so on.

Beside that the rapid of technological developments and starting to shift the values of the noble tradition that has grown long. The cultural messages contained in traditional pattern are rarely heard ang foun in society. Based on this facts, to encourage the steps taken inventory and documentation of local culture in terms of sex education. The cultural phenomena related to languages that will be discussed here, it has uniqueness that can be viewed as something related to ethnolinguistics science.

\section{LITERATURE REVIEW}

The scope of ethnolinguistics including the correlation of language with culture, especially the aspect of investigation the cultural anthropology or anthropology with linguistics. Ethnolinguistics learn about the correlation between language, language use, and culture in general. By knowing the language that is used by the society it will be 
known their culture, because ethnolinguistics examine the language and culture that apply in certain society.

Javanese language and culture in this paper be understood according to the author's and ethnolinguistic has the local wisdom. The understanding about local wisdom as a tool of knowledge and practices that can be used to solve the problemb is faced in a good and right way (Ahimsa, 2007:17). It can be assumed that there are many interesting points to be discussed scientifically, especially on anthropological linguistics that regrad to the position of language in the broader og socio-cultural context to promote and sustained the cultural practices and social structures (Foley, 1997:3).

In this case, the purpose of ethnolinguistics about Javanese language is to examine the phenomenon of Javanese language expression in lerarning about Javnese sexual education that is reflected their local wisdom and the demands of their life. Besides, it wants to describe the behavior that is used to achieve the welfare of life which is reflected in verbal behavior, concerns way of life, the world view, the patterns thought of reflected the cognition system in Javanese society regarding of sex education.

Further more, Subroto (2010:2) explains that Ethnolinguistics as a linguistic which is focus on the finding that will be donated in cultural systems such as grammar, vocabulary, and understanding of contextual meaning. Basically, Ethnolinguistics tries to classify of cognition, views of life, and mindset based on the empirical date of language and more dependent on lexicon dimension along with semantics dimension of the language and culture of the owner. Therefore, language is more related to collective mindset and knowledge systems of society.

The existence of ethnolinguistic study is expected to explain the feeling of anthropological linguistics that studies the language of society (Fernandes, 2009:19). The feeling in Javanese language means to understand the delivery of sexual education shows that language is not understood to stand linearly as a sequence of sounds, but it is a part of totality expression in society based on the cultural context along with all values of the expression in individually or groups life. Through the data of linguistic facts will be obtained and interpreted the important information about the knowledge system that contained of it (Foley, 2001:3-5).

\section{METHOD}

This research is a descriptive qualitative research. The data source of this research are six Javanese literary song called Tembang there are Serat Wewadining Palakrama, Serat Asmaragama, Serat Pangawikan Lakirabi, Marta Pangrawit, Serat Wirasating Wanita, and Serat Centhini. Then, the data of this research are linguistics data which is consist of words, clause, sentences, word formation, showing the style of language about Javanese sexual education in tembang.
Techniques of collecting data in this research used library technique and contain analysis. The process of data analysis is interactive, by using: data reduction, data display, and conclusion (Sutopo, 1996:)

\section{RESUlT AND DISCUSSION}

\section{The Utilization of Javanese Sex Education in Six Javanese Literary}

It can be said that one of the foundations of Javanese culture is manners and feeling that do not want to hurt the others. Therefore a person who claims to be a Javanese should be gentle, speaking with a light intonation and does not harm others. The sexual texts in six Javanese literary are Serat Wewadining Palakrama, Serat Asmaragama, Serat Pangawikan Lakirabi, Marta Pangrawit, Serat Wirasating Wanita, and Serat Centhini is one of Javanese culture that is used to realize it above. With Javanese wisdom to express the teaching of sex, direct confrontation can be avoided and gives the people a chance to think of the message we give to it.

The sexual texts in six of literature are a form of traditional communication in Javanese society by providing signs through of figurative language, attributes, etc that have certain meanings. In visible, sexual texts displayed the signs, it often making their multi-interpretative meaning. There are not many young people who understand that in every word have an implied meaning contained in it.

\section{a. Serat Wiwadining Palakrama}

Serat Wiwadinging Palakrama consist of how a husband and wife have a good married. This letter teaches about how the people should be able to feel the pleasure of marrying (ngrasakake sarine wong bebojoan). The enjoyment of marriage is not only the physical fulfilled such as food and clothing, but also in sexual intercourse between husband and wife. In Javanese languages called sare kekumpulan.

(1) Ing kene mula disêbut'ake sarana cêtha "garwane", amarga ana ing pawulangan kang katêrangake ana ing buku iki, kabèh mau tumanjane mung maligi tumrap kanggo wong kang kapingin ngrasak'ake sarine wong bebojoan. Sarine wong bebojoan kuwi, kajaba ing bab karukunane ing anggone padha urip lahir sarana bêbrayan, gotong royong sarana bêbarêngan anggone angudi bisane kacukupan mungguh ing bab kabutuhane urip, kaya ta: panggolèke sandhang-pangan, pangruktène marang putra-putra, kaprigêlane nênata omah lan sapanunggalane, uga kang pêrlu digatèkake tumrap uripe ana ing sare kêkumpulan. Urip kang kawastanan sampurna kuwi, lênggahe ana cukuping butuh urip lahir, lan sampurnane (sênênge) uga ing bab nêtêpi kuwajibane lanang tumrap mênyang wadone, utawa uga wadon marang rakane (hal.1) 'di sini disebutkan dengan jelas 'suami/istri', sebab dalam pengajaran yang diterangkan di buku ini, semua ini ditujukan untuk orang yang ingin 
merasakan kenikmatan berumah tangga. Kenikmatan berumah tangga itu, selain dalam hal kerukunan menjalani hidup secara kekeluargaan, gotong royong mengutamakan kebersamaan supaya cukup dalam memenuhi kebutuhan hidup, seperti mencari sandang pangan, memelihara putra-putri, kepandaian menata rumah dan sebagainya, juga perlu diperhatikan yaitu masalah tidur atau berhubungan badan. Hidup yang dikatakan sempurna, ketika cukup kebutuhan lahir, dan akan lebih sempurna apabila bisa memenuhi kuwajiban seorang laki-laki kepada istrinya, atau istri kepada suaminya'.

Life is perfect if the husband can carry out his duties to the wife, and vice versa. The obligation of the husband to give a wife's inner physical, sometimes it is overlooked by many people. Similarly, as a wife in serving her husband is rarely given the attention.

\section{b. Serat Asmaragama}

Serat Asmaragama is a guide for the man to learn how to perform an intercourse 'saresmi' between husban and wife. When they doing an intercourse or saresmi is not expected to upset his wife. They are various things that make the wife has disappointment experience, such as lack of fulfilled food needs, clothes, less satisfied when she gets an intercourse, less satisfied with the wealth or services of her husband so she wans another man, or tempted on the intelligence of others, and for the last is lack of the facilities that he has.

(2) Sêrat Asmaragama punika piwulang tumrap dhatêng para priya, supados sami amarsudia kasidaning lampah patraping sarêsmi,...sampun ngantos adamel cuwaning wanodya.. cedaning wanodya wau awit saking sabab nêm prakawis, 1) awit saking kirang boga, 2) awit saking kirang busana, 3) awit saking kirang marêm ing asmara, 4) awit saking melikan ing kakung liyan, 5) awit saking melikan kenging guna, lan 6) awit saking kirang sarana.

'Serat Asmaragama ini petunjuk kepada para lakilaki supaya mau mempelajari bagaimana melakukan saresmi 'bersenggama'... jangan sampai membuat kecewa hati perempuan.. Kekecewaan perempuan berawal dari enam hal, 1) karena kurang terpenuhi kebutuhan makan, 2) kurang terpenuhi kebutuhan pakaian, 3) kurang puas ketika berhubungan badan, 4) karena tergoda laki-laki lain, 5) karena tergoda pada kepintaran orang lain, dan 6) kurangnya sarana prasarana.

The things that make someone has unfavorable marriage life are the lust of wanting to eat too much, madon or have a mistress, gambling, using the opium, drinking, and enjoying stealing.

(3) Dene awoning kalakuan punika wontên nêm prakawis yaiku 1) mangani /baruwah = ngangsa- angsa, 2) madon /rêmên lêlangên èstri, 3) main Irêmên ngabotohan, 4) madati /nyêrèt, 5) minum Irêmên wuru, lan 6) maling /rêmên nyênyolong.

'Adapun tingkah laku yang tidak baik disebabkan enam hal yaitu 1) nafsu ingin makan yang berlebihan, 2) madon 'atau senang main perempuan', 3) berjudi, 4) memakai candu, 5) minum minuman keras, dan 6) senang mencuri'

A husband and wife are very happy in marriage, can carry out the obligation of saresmi 'intercourse' with the wife or husband, and blessed with a clever child, blessed with a rank, and blessed with rich or the abundant treasure. It should starting how a couple doing a cumbana/saresmi (an intercourse). Therefore, how to implement a good intercourse must be mastering the technique. Sexual intercourse for the Javanese society is glorious and sacred. Husband-wife relationship are like painting a seeds. The seeds planted should be good seeds and then can be a good child as well.

(4) Bêgjaning bapa punika manawi putranipun gadhah kadrajatan tigang prakawis 1. guna 2. wirya 3. kaya, inggih punika ingkang nyuwargakakên bapa. 'Keberuntungan ayah jika memiliki putra dan dikaruniai tiga hal yaitu 1. guna 'kepandaian', 2. Wirya 'pangkat', dan 3. Kaya 'kekayaan'.

\section{c. Serat Pangawikan Lakirabi}

Serat Pangawikan Lakirabi mentions if a man or woman that is unmarried will feel the problem, it lies because they cannot yet get married. As for the married couple will also feel it too, this problem lies because they are married. Until the unmarried person must also feel the problem, it lies because he is not married.

Based on the root of the problems, actually it is caused by the human itself. Something will be a problem or not, it is depending on the wishes of this person. Man's desire is like mungkret 'can be elongate or shrink'. That all is living the people. Sometimes it feel so hard, but sometimes it feels happy because the demands of semat, drajat, and kramat.

Semat is the body wishes to live on easy street, so everyone will want to be wealth. Drajat is the heart wishes, wants to be loved, praised, and etc, so someone would want to be smart, want to rank, or high position. Kramat is the desire of the mind like to rule, be praised, followed, and so on. All three eventually reach the wish or desire to do an intercourse or married.

(5) Tiyang jalêr èstri, yèn dèrèng lakirabi inggih ribêd, ribêdipun inggih anggènipun dèrèng lakirabi. Dene ingkang sampun lakirabi inggih ribêd, ribêdipun inggih anggènipun sampun lakirabi. Ngantos dumugi ingkang botên lakirabi inggih mêksa ribêd, ribêdipun inggih anggènipun botên lakirabi (Hal. 5).

'Seorang laki-laki maupun perempuan jika belum menikah akan merasakan masalah, masalah itu 
terletak karena dia belum bisa menikah. Adapun yang sudah menikah juga akan merasakan masalah, masalah itu terletak karena dia sudah menikah. Sampai kepada orang yang tidak menikah juga pasti merasakan masalah, masalah itu terletak karena dia tidak menikah.

\section{d. Marta Pangrawit}

In Serat Marta Pangrawit mentioned about the married life, the relationship between husband and wife is like someone who is playing gamelan orchestra. Its like someone that playing kendhag, rebab, and bonang.

(6) Ana kang nerangke kendhang/ jare iku pasemone ngaurip/ yèn wis kaya kendang iku/ tinutup kiri kanan/ tegesira wis nutup hardaning kalbu/ bisa anuntun irama/ iramane wong ngaurip// (Pupuh 6, Pangkur bait 9)

'ada yang menerangkan seperti kendang, katanya itu simbolisme kehidupan, kalau sudah seperti kendang, ditutup kanan kiri, maksudnya sudah bisa menutup hawa nafsu, akhirnya bisa mengikuti irama, irama kehidupan.

Life is like playing kendhang. Physically the trip of the right end of a drum is covered with animal skin. This is implies that one should be able to cover the adverse desires either to his right or to his left.

(7) Ana kang negesi rebab/ jare iku pralambanging dumadi/ dènira sami tumuwuh/lantaran yayah rena/ saranane lanang wadon kudu kumpul/ barang darbèke wong lanang/ mlebu kawadonan èstril/ (Pupuh 6, Pangkur bait 10)

'ada yang mengartikan seperti rebab, itu perlambang hidup, kamu bisa hadir ke dunia, karena ulah orang tua, dengan cara laki-laki dan perempuan berkumpul/bersenggama, barang kemaluan laki-laki, masuk ke dalam kemaluan perempuan'

(8) Mila kosok rebab ikal ora liya aran rangkung kang nami/ tegese barange kakung/ dianggo nggosok kawat/ kawat iku kawadonan tegesipun/ kang mangkono iya kenal masa borong ngriku samil/ (Pupuh 6, Pangkur bait 11)

'itu sebabnya rebab harus digosok, atau disebut dengan istilah rangkung, artinya barang kakung 'barang/kemaluan laki-laki', diperuntukkan untuk menggosok kawat, kawat itu kawadonan/barang miliki perempuan, seperti itulah kalau diartikan, terserah yang ingin mengartikan.

The intercourse process is like a person that playing a rebab. Physically playing a rebab by swiping or hoistbags rubbed into a wire. Like intercourse is also done by rubbing the basket of male genitals 'kakung' into the female genitals.

(9) Disambung nerangke bonang/ bonang lanang manggone anèng nginggil/ bonang wadon ngandhap iku/ pancèn iku wis nyata/ yèn cumbana sing lanang nginggil nggènipun/ wedoke sing anèng ngandhap/ kaya bonang uwis persis// (Pupuh 6, Pangkur bait 12)

'disambung menerangkan bonang, bonang lanang berada di atas, bonang wadon berada di bawah, itu memang benar, kalau bersenggama maka laki-laki posisi di atas, perempuan berada di bawah, seperti layaknya bonang.

Sex is likened to someone that palying rebab or bonang. Narrated during the intercourse position of the man above and the position of women below. Sexual intercourse in Java remains that is depicted politely with parables. Sex seems to be something glorious, sacred, and not a dirty one.

\section{e. Serat Wirasating Wanita}

Serat Wirasating Wanita contains of the woman character based on their birth and market days. In this letter mentioned that a woman has a various temperament or characters according to weton 'day of birth in Java'. This is intended as a learning for a man in understanding the charecters of his wife or future wife. A husband mus be covered the shortage of a wife because in essence every human must have weakness. The weakness should not be ameans to vilify a partner, but ir should be used as a whip to cover any shortcoming. A sense of mutual understanding of each other is what should be a husband and a wife.

(10) anak putu dipun emut/ kang wus kalêbu ing tulis/ yèn Jumungah Pon wêtonnyal tan sabar kaku kang ati/ watêk wani mring wong tuwal lan ora sinungan sugih// (Pupuh 1 Kinanthi bait 4)

'anak cucu perlu diingat, yang termasuk dalam tulisan, kalau Jumat Pon hari lahirnya, tidak sabar serta kaku hatinya, wataknya berani terhadap orang tua, dan tidak dikaruniai kekayaan'

(11) Jumungah Wage puniku/ tan pantês kinarya rabil groboh ora amicaral dene gêlêm anglakonil panggawe kang ala ngiwal tan ajêg pikirirèkil/ (Pupuh 1 Kinanthi bait 6)

'Jumat Wage itu, tidak pantas dijadikan istri, cerobo tidak pandai bicara, dan senang melakukan, pekerjaan yang tidak baik, sering tidak menentu pemikirannya'

(12) Jumungah Kliwon puniku/ kawruhane dèn nastiti/ pikirane rada lumrah/mring wong tuwa wêdi asih/ nging kêdhik wani mring priyal jinurung sugih rêjêki// (Pupuh 1 Kinanthi bait 7)

'Jumat Kliwon itu, ketahuilah dengan sungguhsungguh, pemikirannya tertata, kepada orang tua patuh dan mengasihi, tetapi sedikit berani kepada suami, dikaruniai banyak rejeki dan kekayaan'

\section{f. Serat Centhini}


Sex education is taught in Serat Centhini always ask the people to be aware of the origin of human happiness. In this letter is mentioned with the origin term 'bibit kawite'.

(I3) Pamarsudining sarêsmi / kang wus sun-gêlar sadaya / kanggo srana lantarane / dènnya yun angawruhana / mring asal wijinira / manungsa sajatinipun / kasbut têmbung paribasan // (Serat Centhini Jilid III Pupuh 191 Asmaradana bait 21)

'Pengetahuan cara bersenggama, yang sudah saya uraikan, sebagai sarana dan alat, untuk mengetahui, tentang asal-usul kelahiran, manusia sebenarnya, seperti tersebut dalam peribahasa'.

(14) Sing sapa wonge tan uning / marang wiji asalira / sayêktine nora wêruh / mring jati paraning sêdya / kang têmbe wêkasannya / kacrita kurang satuhu / mring sampurnaning kamuksan // (Serat Centhini Jilid III Pupuh 191 Asmaradana bait 21)

'Barang siapa tidak mengetahui, asal mula kejadiannya, sesungguhnya tidak mengetahui, tujuan sejati manusia hidup, dan akhirnya, sungguhsungguh tidak akan mengetahui, kesempurnaan sebuah kematian'.

Sex in Javanese is included in the case of taste. At the moment and after the connecting occurs of soul and body. Sex is not just a biological relationship, but there is a concept of Javanese spiritualism, there is an action 'patrap' to respect others, understanding of each other, and in order to continue the worthy children of virtuous descent.

In Serat Centhini, there is a linguistics phenomenon that is typical and associated with sexual activity i.e wiji asalira, jati paraning sedya, and sampurnaning kamuksan. It can be concluded that before doing the sexual intercourse, we should always remember that where we came from and who will return to God in good conditions, believe in perfect death.

\section{The Reflection of Sexual Education Texts of Local Wisdom in Javanes Society (Ethnolinguistics Review)}

The research of Javanese culture and the use of Javanese language especially in the disclosure of sex is very interesting because it has own uniqueness. It contains a view of life, a world view, a collective mindset of the Javanese society that is expressed through nuanced texts of sexual education.

Javanese language is used intimately for all activities of Javanese life, both of the outward and inner are actually hidden in the Javanese language. The Javanese in using the language always included the fullest or sensitive sense of the language, proving that the Javanese language in the disclosure of Javanese sexual education when viewed in semantic contains a description of the wealth of the souls of Javanese people.

Language has a primary function that means to communicate to establish and generate thoughts in the widesr sense and to develop reason. The text of Javanese sexual education were used by the Javanese society as the expression of the Javanese human soul. Most of these, the Javanese word contain of the effective touch. So it has the potential to contact with taste and feelings. In this case, the texts of the teaching Javanese sexual intelligence in six Javanese literary contain of an emotive aura and poured the taste value by the wearer. Therefore the reader of thus sexual texts, it will have a very strong emotional effect or have the ability to produce certainly emotional effects on the listener.

On the other hand, the texts of Javanese sexual education in six Javanese literary are meant precisely to express certain emotive values or views, taboo activities not directly espressed, but it is used more polite Javanese language such as metaphor, similie, senepa, and so on.

\section{V.CONCLUSION}

The existence of Javanese Ethnolinguistics research about the correlation of language and culture in the delivery of Javanese sexual education can be used as an effort to preserve the language and means of personality and identify formation. Sexual terms in six literary works containing of sexual themes exist in monomorfemis such as saresmi, cumbana, main, or polymorphism there are madati, mangani, madoni, and kawadonan. The polymorphic of kawadonan 'female genitalia', because it is consist of two morphemes such as free morpheme of wadon and ka-an bound morpheme. Something as a phrases there are sare kekumpulan, and sarine wong bebojoan. In the phrase of sare kekumpulan consist of two direct elements namely sare and kekumpulan. So, sare kekumpulan is formed from sare+kekumpulan.

Ethnolinguistic studies on the use of sexual language in six Javanese literary are found on many Javanese language related views of life. Such as urip kawastanan sampurna... ora mung cukuping butuh urip lahir,.. uga ing bab nêtêpi kuwajibane lanang tumrap menyang wadone 'life is nor perfect, not only fulfilled needs of birth, also fulfill the obligation of a man to his wife. Something that make the husband and wife relationship is not happiness are mangani, madoni, main, madat, drink, and thief. Husband and wife relationship is like someone who is playing gamelan orchestra, and so on. The utilization of wisdom Javanese language in conveying Javanese sex education actually reflects the local wisdom of Javanese language and culture. When viewed in a philosophical sense, the texts of Javanese sexual education in six literary contain the noble or superior values of education.

Initiating the introduction of religious values embodied in Javanese sexual texts, is expected to build selfidentity and embed the filters in selecting outside cultural influences. If the local cultural values are successfull, a strong cultural identity will be established, and ultimately will be able to stem and filter if any external cultural influences the other shapes, so that the case of vacuum of the cause of moral decadence can be avoided. 
Publishers.

\section{References}

Ahimsa-Putra, Heddy Shri. 2007. "Ilmuwan Budaya dan Revitalisasi Kearifan Lokal. Tantangan Teoretis dan Metodologis". Pidato Ilmiah Dies Natalis FIB UGM ke 62 di Yogyakarta. Yogyakarta: Gadjah Mada University Press.

Edi Subroto, D. 2010. "Etnolinguistik". Surakarta: Program Pascasarjana Universitas Sebelas Maret.

Foley, W. A. 1997. Anthropological Linguistics An Introduction. University of Sydney: Blackwell
Fernandez, Inyo Yos. 2009. "Keanekaragaman Bahasa Kerabat dan Kearifan Lokal Komunitas Subetnik Dayak di Kabupaten Kutai Barat, Kalimantan Timur". Artikel dimuat dalam Medan Bahasa. Jurnal Ilmiah. Departemen Diknas. Sekretaris Jenderal Pusat Bahasa. Balai Bahasa Surabaya, ISSBN 1907-1787.

Poerwadarminta, W.J.S. 1939. Baoesastra Djawa. Batavia: J.B. Wolter Uitgevers Maatchappij N.V. Groningen. 